\title{
Preface and Acknowledgments
}

On the morning of Wednesday, November 9, 1960, Democrats across Texas woke up, and all was well. Their party had wrested back the White House, occupied by the opposition for the last eight years, and the new vice president of the United States was one of their own. Texas had returned to its traditional roots, and the state had been carried by the Democratic presidential candidate once again, albeit in a too-close election. Beyond that one contest, there was little concern. All thirty statewide elective positions, from governor to court of criminal appeals, were in the hands of Democrats. The same picture would be drawn in the Texas legislature: 181 Democrats and no Republicans or anyone else. One lone Republican would sit, however, among the twenty-four Members of Congress representing Texas. Clearly, after a little aberration in the Eisenhower elections, Texas was once again a one-party Democratic state.

Fast-forward fifty years to November 3, 2010, once again the day after an election, and the picture is dramatically different. There was again a Democrat in the White House, but he had achieved election without the support of Texas, a state that had not voted for a Democratic presidential candidate in thirty-four years. Moreover, every statewide elective office was now held by Republicans; no Democratic candidate had won a single statewide position in sixteen years. Representing Texas in Washington was a congressional delegation of twenty-five Republicans and nine Democrats. Republicans controlled the Texas Senate by a margin of nineteen to twelve and had elected ninety-nine of their party to the 150-seat Texas House of Representatives, a number soon to be enhanced by the switch of three Democratic state representatives to the GOP. What had been for more than a century a one-party Democratic state was now clearly a predominantly Republican state. 
How did this transformation of Texas politics take place, and what do the recent changes imply for the future? That is the story to be told on the following pages, beginning with a brief overview and background information on Texas itself, followed by a description of the four categories of counties in the state. Attention is then drawn to the extent of political competition in Texas during the 112 years of statehood prior to the election of 1960. It's a story of various factions and forces attempting to compete as a political party against the dominant Democratic Party, with only sporadic and localized success. More recently, however, it is also the story of conflict among ideological groupings within the dominant party, conflict that provided a modicum of choice for Texas voters and that ultimately facilitated the development of a viable alternative political party.

From the end of the Reconstruction era in Texas and the return of the ex-Confederates to the electorate in 1873 until the 1960s, Texas political competition took place within a one-party system. As was true in other states of the Confederacy, that one political force was the Democratic Party. With few exceptions in isolated parts of the state, especially the German-settled Hill Country, Democrats won all elections for public office, Republican candidates rarely appeared, and the actual selection of public officials took place in the Democratic primary.

The first movement away from a one-party system began to appear with the emergence of presidential Republicans, individuals whose opposition to many policies of the New Deal and the national Democratic Party led them to support a Republican candidate for president. At the same time, these individuals continued to view themselves as Democrats and continued to vote in the Democratic primary. By the 1960s and 1970s, cracks were beginning to appear in the Democratic dominance of the state's politics, first with the election of John Tower to the United States Senate in 1961 and then several years later the election of Bill Clements as governor. Competition developed first in the state's major urban areas, for top-ofthe-ticket candidates. As these metropolitan areas expanded geographically, a Republican base began to develop in their suburban counties. At the same time, competition spread to the smaller, outlying metropolitan statistical areas where race, ethnicity, economic base, and extent of union membership had an impact on the degree of competition that developed. It would be much later before partisan change would occur in many of the state's rural counties.

By the 1980s Texas had entered into a brief period of true two-party competition, with both major parties able to elect a number of candidates, 
fewer contests that were settled in the party primary, and growing competition expanding to down-ballot candidates. During the period from 1978 to 1998 the office of governor alternated between the two parties every four years, and for most of this period the state was represented by one Democrat and one Republican in the United States Senate. Beginning with the election of 1996, however, the Republican Party has won every statewide election, eventually acquiring a majority in both chambers of the Texas legislature as well as the congressional delegation. As the twenty-first century began, Texas appeared to have entered a period of one-party politics once again, albeit not to the overwhelming extent of Democratic domination in the previous era.

As the geographical spread of party competition was taking place, so too was it moving down the ballot, limited at first by the visibility of the office. Thus, party competition first took hold in federal elections, followed by gubernatorial elections and then those for the state legislature, bypassing the lower-profile statewide executive and judicial offices. For the individual Texan, changes in voting behavior preceded changes in party identification, which, in turn, preceded changes in primary election participation. Yet, to a large extent, individual conversions have been less significant than the inclusion of new voters in the electorate, comprising both new residents and younger voters. In the following pages, the changes in party competition will be viewed using a number of measures, including perceived party identification, actual affiliation with a political party by participating in its primary, the performance of candidates for statewide elective offices, representation in the U.S. House of Representatives and the state legislature, elections for county offices, and the extent and nature of straight-ticket voting.

Without question, this fifty-year period witnessed a phenomenal change in Texas population numbers, composition, and location. The state has undergone a transition from a predominantly rural to an overwhelmingly urban society, witnessed the influx of new residents from other states and nations, and experienced the diversification of its economy. The economic base of the state has broadened to include new industries not even known fifty years ago, from semiconductors to biomedical research. As the state has changed, so too has the electorate, and these changes opened up the opportunity for alternative political forces to develop. Eventually, the longstanding practice of contesting ideological positions and elections within one single political party seemed a less viable path to follow. 
This book focuses on the period from 1960 to 2010, but the story of the transformation of Texas politics will continue into the future as Texas meets the challenges of the twenty-first century. The Texas of 1960 is not the Texas of 2014, nor is it the Texas in which our children and grandchildren will make their lives. As the state and society change, so too will our political parties and the choices they provide to Texas citizens. To predict where we are going is much more difficult than to describe where we have been. At the same time, understanding the past is an important component to being prepared for the future. In this spirit, the pages that follow describe the political changes in Texas politics since 1960, closing with some predictions regarding changes still to come. My hope is that this work will in some way contribute to an understanding of the significant modifications in party competition that have taken place in Texas in the past fifty years.

\section{Acknowledgments}

In attempting to present an overview of the changes and continuities that have occurred in political competition since 1960, I am indebted to the efforts of many previous authors and researchers on various aspects of Texas political history. Too many to mention here, their publications have been cited in the endnotes. Without these contributions, and those of the authors of several unpublished works, the current manuscript would not have been possible.

Additionally helpful to my research were the archival materials at the Dolph Briscoe Center for American History, the University of Texas at Austin; the Lorenzo de Zavala State Archives and Library, Austin; the Perry-Castañeda Library, the University of Texas at Austin; Southwestern University Special Collections, Georgetown, Texas; and the University of Texas at San Antonio Libraries Special Collections. My thanks go to the archivists and staff at these valuable collections of historical records.

Many individuals have contributed suggestions for this work, and I am especially grateful for those who read and critiqued parts or all of the manuscript: Ernest Angelo Jr., Paul Burka, David O'Donald Cullen, Gregory Davidson, John Knaggs, Steven Munisteri, and Peck Young. While their recommendations have improved this manuscript immeasurably, the final product and the conclusions herein are solely mine.

This work would not have been possible without the interest and support of Casey Kittrell, my acquisitions editor; Theresa J. May, editor-in- 
chief; and the entire staff at the University of Texas Press. Working with them has been a most pleasant experience. In the end, however, my greatest appreciation is given to Judith Abramov Thorburn, my proofreader extraordinaire, computer expert, best friend, and wife. Without her support, I could not have completed this effort. 
THIS PAGE INTENTIONALLY LEFT BLANK 